\title{
APLIKASI METODE BORDA COUNT UNTUK PENENTUAN PEMENANG PEMILIHAN KEPALA DAERAH
}

\author{
SHAKTIVA NUGRAHA, SUSILA BAHRI, MONIKA RIANTI \\ Program Studi S1 Matematika, \\ Fakultas Matematika dan Ilmu Pengetahuan Alam, Universitas Andalas, \\ Kampus UNAND Limau Manis Padang, Indonesia. \\ email : shaktivanugraha94@gmail.com
}

Diterima 29 November Direvisi 3 Desember 2019 Dipublikasikan 12 Januari 2020

\begin{abstract}
Abstrak. Pada makalah ini, Metode Borda Count diaplikasikan untuk menentukan pemenang pemilihan walikota Padang Panjang. Pertama kali, keempat calon walikota diberi nomor urut sesuai dengan ketetapan KPU Padang Panjang. Pada kuesioner setiap pemilih menetapkan urutan pilihan sesuai keinginannya terhadap calon walikota. Data hasil pilihan berdasarkan keinginan tersebut dikumpulkan dan diungkapkan dalam bentuk matriks bujur sangkar. Selanjutnya karena terdapat empat calon, pilihan pertama dari pemilih diberi nilai 4 sedangkan pilihan kedua dan seterusnya berturut-turut diberi nilai 3,2 dan 1. Poin Borda Count tersebut dinyatakan dalam bentuk matriks baris 1 $x$ 4. Hasil perkalian matriks data hasil pilihan dan matriks poin Borda Count tersebut menghasilkan jumlah suara yang diperoleh oleh masing-masing calon walikota. Dari hasil penggunaan metode ini, dinyatakan bahwa pasangan calon Mawardi-Taufiq Idris sebagai pemenang walikota Padang Panjang.
\end{abstract}

Kata Kunci: Borda Count, matriks, pemilihan

\section{Pendahuluan}

Pada tahun 2018 yang lalu, Komisi Pemilihan Umum Republik Indonesia (KPU RI) kembali melaksanakan Pemilhan Kepala Daerah (Pilkada) serentak. Pada tahun tersebut terdapat 171 daerah melaksanakan pilkada serentak dengan rincian 17 provinsi memilih gubernur, 39 kota memilih walikota dan 115 kabupaten memilih bupati [3]. Dari 171 pemilihan kepala daerah tersebut, di provinsi Sumatera Barat ada 4 kota melaksanakan Pilkada yaitu Padang, Sawahlunto, Pariaman dan Padang Panjang.

Selama ini berdasarkan sistem pemilihan dalam pilkada, pemilih hanya boleh memilih satu pilihan saja. Jika pemilih memilih lebih dari satu pasangan maka suara pemilih tersebut dianggap tidak sah sehingga tidak diperhitungkan lagi. Metode pemilihan ini memiliki kelemahan karena pemilihan yang dilaksanakan tidak mempertimbangkan urutan keinginan dari pemilih yang menyatakan pendapat pemilih terhadap masing-masing calon. Hal ini mengakibatkan calon yang terpilih terkadang 
tidak sesuai dengan aspirasi pilihan masyarakat secara keseluruhan. Selain itu dengan menggunakan metode ini, proses pemilihan ada kalanya diulang kembali apabila tidak ada calon yang memperoleh suara lebih dari 50\% suara, kecuali tergantung KPU mengatur saat pemilihan dilaksanakan. Akibatnya biaya pilkada menjadi meningkat. Untuk mengatasi kelemahan tersebut, diperlukan suatu metode pemilihan yang didasarkan pada urutan keinginan pemilih, yang lebih menggambarkan dan mengungkapkan aspirasi pilihan para pemilih.

Metode Borda Count adalah salah satu metode pemilihan yang dapat digunakan dalam memilih kandidat politik favorit suatu pemilihan [4]. Metode ini dalam pelaksanaannya menggunakan aplikasi matematika seperti fungsi faktorial dan perkalian matriks. Metode Borda Count ditemukan oleh Jean-Charles Chevalier de Bord (4 Mei 1733-19 Februari 1799) yang merupakan seorang ahli matematika, ahli fisika, dan pelaut Prancis.

Peneliti memilih kota Padang Panjang sebagai objek penelitian karena kota Padang Panjang memiliki 4 calon, sedangkan tiga pemilihan daerah lainnya memilki calon kurang dari 4. Metode Borda Count lebih cocok diterapkan untuk $n \geq 3$, pada penelitian ini $n$ bernilai 4 . Apabila dibandingkan hasil dari pemilihan yang dilaksanakan oleh KPU bisa sama atau berbeda dengan metode Borda Count.

Pada pilkada 2018, Kota Padang Panjang memiliki 4 kandidat pasangan calon walikota sesuai urutan yaitu (1)Mawardi - Taufiq Idris, (2)Hendri Arnis - Eko Furqani, (3) Rafdi Meri Syarif - Ahmad Fadly dan (4) Fadly Amran - Asrul.

\section{Landasan Teori}

Definisi 2.1. [2] Matriks adalah jajaran empat persegi panjang dari bilanganbilangan. Bilangan-bilangan dalam jajaran tersebut disebut entri dari matriks.

Suatu matriks A dan B dapat dikalikan jika jumlah kolom dari matriks A sama dengan jumlah baris pada matriks B.

Definisi 2.2. [2] Jika $A$ adalah matriks $m \times r$ B adalah matriks $r \times n$ maka hasil kali matriks $A B$ adalah matriks $m \times n$.

Misalkan $A$ merupakan himpunan berhingga, maka jumlah elemen berbeda di dalam $A$ disebut kardinalitas dari himpunan $A$, dinotasikan sebagai $n(A)$ atau $\# A$ [5]. Suatu fungsi faktorial $f: N \rightarrow \mathbb{Z}^{+}$dinotasikan dengan $f(n)=n$ !. Nilai $f(n)=n$ ! adalah hasil kali dari bilangan bulat positif $n$ yang pertama sehingga $f(n)=1 \times 2 \times \cdots \times(n-1) \times n$ dan $f(0)=0 !=1[7]$.

\subsection{Formula Slovin}

Formula Slovin adalah suatu formula yang digunakan untuk menentukan banyak sampel yang diperlukan dalam suatu penelitian [8]. Formula Slovin tersebut adalah

$$
n=\frac{N}{1+N e^{2}},
$$

dimana $n$ adalah banyaknya sampel, $N$ adalah jumlah populasi dan $e$ adalah batas toleransi kesalahan. Batas toleransi kesalahan dinyatakan dalam persentase. Semakin kecil toleransi kesalahan, semakin akurat sampel menggambarkan populasi. 


\subsection{Metode Borda Count}

Metode Borda Count merupakan suatu metode yang dapat digunakan dalam pengambilan keputusan untuk suatu pemilihan dari sekelompok pilihan [4]. Pemilih atau pemberi suara (voters) melakukan perankingan terhadap kandidat atau calon yang akan dipilih, yang disusun berdasarkan pilihan (preference). Metode ini menentukan pemenang dari suatu pemilihan dengan memberikan jumlah poin tertentu untuk masing-masing kandidat sesuai dengan posisi yang telah ditetapkan.

Langkah-langkah dalam metode Borda Count diberikan berikut ini:

(1) Tetapkan poin Borda untuk tiap kandidat dan konstruksi matriksnya. Secara umum, jika terdapat $n$ kandidat, maka $n$ poin ditetapkan untuk pilihan pertama, $n$-1 poin untuk pilihan kedua, $n$ - 2 poin untuk pilihan ketiga, dan seterusnya hingga pilihan terakhir.

(2) Buat matriks dari data pilihan yang diperoleh. Data pilihan yang telah dipilih oleh pemilih dinyatakan dalam bentuk matriks.

(3) Lakukan perkalian dari matriks yang diperoleh pada langkah 1 dan 2.

(4) Nilai untuk tiap kandidat selanjutnya dihitung. Kandidat dengan nilai tertinggi dinobatkan sebagai pemenang Borda.

Skor Borda yang ditunjukkan dengan $B S(A)$ dapat juga dihitung dengan formula $B S(A)=(n) \times \# i \mid i$ meranking A yang pertama $+(n-1) \times \# i \mid i$ meranking A yang kedua $+\ldots+2 \times \# i \mid i$ meranking A kedua terakhir $+1 \times \# i \mid i$ meranking A terakhir [1]. Kandidat dengan skor Borda tertinggi adalah pemenang.

\section{Pembahasan}

(1) Mengumpulkan data pemilih serta data pilihan kepala daerah yang akan dipilih oleh masyarakat. Jumlah pemilih dalam pemilihan kepada daerah tersebut adalah 35.948 orang, sedangkan 4 pasangan calon yang akan dipilih sesuai urutan yang telah ditetapkan panitia pemilihan adalah:

(1) Mawardi - Taufiq Idris

(2) Hendri Arnis - Eko Furqani

(3) Rafdi M. Syarif - Ahmad Fadly

(4) Fadly Amran - Asrul.

(2) Menentukan jumlah atau banyak sampel yang akan digunakan. Dengan menggunakan (2.1) maka jumlah sampel dengan toleransi kesalahan $5 \%$ adalah

$$
\begin{aligned}
n & =\frac{35.948}{1+35.948\left(0,05^{2}\right)} \\
& =\frac{35.948}{90,87} \\
& =395,59811 \\
& \approx 396 .
\end{aligned}
$$

(3) Menetapkan kemungkinan urutan pasangan calon yang mungkin secara matematis. Karena terdapat 4 pasangan calon maka banyaknya urutan yang 
mungkin terjadi dalam proses pemilihan adalah $4 !=24$. Urutan-urutan yang mungkin muncul dapat dilihat dalam Tabel 1.

Tabel 1. Urutan Pasangan Calon Walikota yang Mungkin dengan Empat Pasangan Calon

\begin{tabular}{|l|l|l|l|}
\hline $1,2,3,4$ & $2,1,3,4$ & $3,1,2,4$ & $4,1,2,3$ \\
\hline $1,2,4,3$ & $2,1,4,3$ & $3,1,4,2$ & $4,1,3,2$ \\
\hline $1,3,2,4$ & $2,3,1,4$ & $3,2,1,4$ & $4,2,3,1$ \\
\hline $1,3,4,2$ & $2,3,4,1$ & $3,2,4,1$ & $4,2,1,3$ \\
\hline $1,4,2,3$ & $2,4,1,3$ & $3,4,1,2$ & $4,3,1,2$ \\
\hline $1,4,3,2$ & $2,4,3,1$ & $3,4,2,1$ & $4,3,2,1$ \\
\hline
\end{tabular}

(4) Menyatakan data hasil pemilihan kepala daerah dalam bentuk matriks. Berikut ini adalah data yang diperoleh dari 396 sampel pemilih di kota Padang Panjang:

Tabel 2. Sampel Pemilih di Kota Padang Panjang

\begin{tabular}{|c|c|c|c|c|c|}
\hline \multirow{2}{*}{ Nomor Urut } & Nama Calon Walikota & \multicolumn{4}{|c|}{ Pilihan } \\
\cline { 3 - 6 } & & 1 & 2 & 3 & 4 \\
\hline 1 & Mawardi - Taufiq Idris & 88 & 248 & 26 & 34 \\
\hline 2 & Hendri Arnis - Eko Furqani & 136 & 19 & 20 & 221 \\
\hline 3 & Rafdi M.Syarif - Ahmad Fadly & 59 & 103 & 215 & 19 \\
\hline 4 & Fadly Amran - Asrul & 113 & 26 & 135 & 122 \\
\hline
\end{tabular}

Dari data yang dikumpulkan, urutan pilihan yang muncul adalah semua urutan yang terdapat pada Tabel 1 kecuali urutan 1,3,4,2 dan 1,4,2,3. Karena tidak ada satu pun pemilih dari 396 sampel yang memilih urutan tersebut. Dari hasil pengumpulan data maka banyaknya pilihan sesuai urutan pilihan dinyatakan dalam matriks berikut:

\begin{tabular}{|c|c|}
\hline No.Urut & 34 \\
\hline pilihan 1 & $\begin{array}{llll}88 & 136 & 59 & 1\end{array}$ \\
\hline pilihan 2 & $\begin{array}{llll}248 & 19 & 103 & 26\end{array}$ \\
\hline pilihan 3 & $26 \quad 20 \quad 21$ \\
\hline pilihan 4 & $\begin{array}{llll}34 & 221 & 19 & 122\end{array}$ \\
\hline
\end{tabular}

(5) Menetapkan nilai ranking (bobot urutan) untuk masing-masing pilihan serta matriks untuk bobot urutan tersebut. Karena Pemilihan Walikota Padang Panjang mempunyai 4 kandidat maka ditetapkan bobot urutan untuk masingmasing pilihan yaitu :

Dalam bentuk matriks, bobot urutan untuk tiap pilihan pasangan calon 
Tabel 3. Daftar pilihan dan bobot urutannya

\begin{tabular}{|c|c|}
\hline Pilihan & Bobot Urutan \\
\hline 1 & 4 \\
\hline 2 & 3 \\
\hline 3 & 2 \\
\hline 4 & 1 \\
\hline
\end{tabular}

tersebut adalah $\left[\begin{array}{llll}4 & 3 & 2 & 1\end{array}\right]$.

(6) Melakukan perkalian matriks dari hasil yang diperoleh pada Langkah 5 dan Langkah 4. Perkalian matriks tersebut :

$$
\left[\begin{array}{cccc}
88 & 136 & 59 & 113 \\
248 & 19 & 103 & 26 \\
26 & 20 & 215 & 135 \\
34 & 221 & 19 & 122
\end{array}\right]=\left[\begin{array}{lll}
1182 & 862994922
\end{array}\right]
$$

(7) Menetapkan pemenang Walikota. Berdasarkan langkah 6, pasangan calon walikota yang memperoleh nilai tertinggi adalah Mawardi-Taufiq Idris, maka ditetapkan sebagai pemenang dalam pemilihan Walikota Padang Panjang dengan 1182 poin, sedangkan pasang calon lainnya Rafdi M.Syarif-Ahmad Fadly memperoleh 994 poin, pasang calon Fadly Amran-Asrul memperoleh 992 poin, dan pasang calon Hendri Arnis-Eko Furqani memperoleh 862 poin.

\section{Kesimpulan}

Berdasarkan perhitungan yang dilakukan pada penelitian ini dengan menggunakan metode Borda Count maka pemenang walikota Padang Panjang tahun 2018 pasangan calon nomor urut 1 yaitu Mawardi-Taufiq Idris. Metode Borda Count dapat digunakan untuk penentuan pemenang kepala daerah dengan mempertimbangkan urutan keinginan masyarakat. Hasil yang diperoleh yakni pemenangnya adalah Mawardi-Taufiq Idris berbeda dengan hasil yang dilakukan oleh KPU yang mana pemenangnya adalah pasangan Fadly Amran-Asrul.

\section{Ucapan Terima kasih}

Terima kasih kepada Bapak Dr.Jenizon, Ibu Radhiyatul Husna, M.Si dan Bapak Dr.Ahmad Iqbal Baqi sebagai penguji sehingga penelitian ini dapat terlaksana dengan baik.

\section{Daftar Pustaka}

[1] Altman, A. The Stanford Encyclopedia of Philosophy (Summer 2013 Edition), Edward N. Zalta.

[2] Beezer, R. A. 2014. A First Course in Liniear Algebra.Versin 3.40. University of Puget Sound. 
90 Shaktiva Nugraha, dkk

[3] Detik News. 2017.httpa://news.detik.com/berita/d-3479819/ini-171-daerah -yang-gelar-pilkada-serentak-27-juni-2018,diunduh 11 Februari 2019.

[4] Election Theory:Modeling the Voting Process. https : /www.comap.com/product/samples/DiscreteMathCh1 $1_{S}$ ample.pdf, diunduh tanggal 11 Februari 2019.

[5] Munir, R. 2003. Matematika Diskrit. Edisi Kedua. Informatika, Bandung.

[6] Opan. Definisi dan jenis matriks (https://uhyan.com/definisi-dan-jenismatriks.php). Diakses tanggal 11 Februari 2019.

[7] Rossen, K. H. 2012. Discrete Mathematics and Its Application. Seven Edition. Mc Graw Hill.

[8] Sevilla, C. G. 2017. Recearch Methods. Rex Printing Company. Quezn City 